Acta vet. scand. $1970,11,139-155$.

From the Department of Connective Tissue Research, Boston

Biochemical Research Institute, Boston, Massachusetts, USA.

\title{
HYALURONIC ACID IN SYNOVIAL FLUID
}

\author{
VI. EFFECT OF INTRA-ARTICULAR INJECTION \\ OF HYALURONIC ACID ON THE CLINICAL SYMPTOMS \\ OF ARTHRITIS IN TRACK HORSES ${ }^{\star}$ )
}

\section{By}

Nils W. Rydell $\left.{ }^{\star \star}\right)$, Judson Butler and Endre A. Balazs

Traumatic and degenerative arthritis in track horses is a frequent and important joint disorder for which corticosteroids are generally used as the most efficient therapeutic agent. The intra-articular injection of suspensions of water-insoluble salts of corticosteroids offer only temporary improvement in the majority of cases, and prolonged use of the drug can cause considerable damage to the articular cartilage (Chandler \& Wright 1958; Chandler et al. 1959; Zacharic 1965; Salter et al. 1967; Mc Kay 1967 and O'Connor 1968).

The fact that traumatic arthritis frequently occurs in the carpal, tarsal, fetlock and coffin joints of young race horses is responsible for the general opinion that the pathological changes are related to the mechanical stress to which these joints are exposed during racing. Genetic factors and the general nutrition of the animal may, however, also play an important role in the development of this disorder.

In our laboratory during recent years hyaluronic acid of very high molecular weight was prepared from human umbilical cord,

*) This investigation was supported in part by a grant from The John A. Hartford Foundation, New York, and by a Special Fellowship (1F05TW1266-01) from the National Institute of Arthritis and Metabolic Diseases, U. S. Public Health Service.

**) Special Fellow of the National Institute of Arthritis and Metabolic Diseases, U. S. Public Health Service. 
and the sterile preparations were used for the replacement of the liquid vitreous in the eyes of owl monkeys (Balazs \& Sweeney 1966, 1968). It must be pointed out that the liquid vitreous of this animal has a connective tissue compartment that is similar to synovial fluid (österlin \& Balazs 1968). This application of hyaluronic acid was an experimental trial of the replacement of diseased human vitreous in retinal detachment and in severe vitreous opacities and hemorrhage, as suggested earlier (Balazs 1960). Recently the therapeutic value of this hyaluronic acid preparation was tested when it was used as a replacement for the liquid vitreous in retinal detachment. The injection of hyaluronic acid into simian and human vitreous indicates that this biopolymer is well tolerated by this connective tissue compartment and that it does not cause damage to the retina or the lens.

Hyaluronic acid is a copolymer of $\mathrm{N}$ acetylglucosamine and gluronic acid in which the disaccharide units are linked by $\beta$ 1-4 glucoside binding to an unbranched long polymer chain. The physical characteristics of this large polyanionic molecule prepared from various tissues (Blumberg \& Ogston 1957; Laurent 1957; Balazs 1958; Preston et al. 1965) and also from human synovial fluid (Balazs et al. 1967) were studied extensively. It was emphasized that this large molecular weight ( $1-10$ million) biopolymer has a high hydrated specific volume (Blumberg \& Ogston; Balazs 1958; Preston et al.), and is viscoelastic (Ogston \& Stanier 1953; Balazs 1966; Gibbs et al. 1968).

The importance of hyaluronic acid in the physiology and pathology of synovial fluid is well known (for review see Sundblad 1965). The viscoelastic properties of this biopolymer make it extremely suitable for the lubrication of cartilage and tendon surfaces (Balazs 1968). The importance of hyaluronic acid in the physiology and pathology of the joint gained new significance following 2 recent discoveries. Fir $s$, histochemical, chemical and electron microscopic investigations showed that a $1-10 \mu$ thick layer, which contains hyaluronic acid and proteins, covers the surface of articular cartilage (Balazs et al. 1966; Balazs 1968). This layer becomes thicker with increasing age and with degenerative disorders of the joint. Second, the viscoelastic properties of synovial fluid change with aging in such a way that the dynamic elasticity decreases, especially at high shear frequencies. Interestingly, the concentration of hyaluronic acid in the joint and the molecular size of the biopolymer 
are not changed. In osteoarthritis, however, the decrease of elastic modulus is accompanied by a decrease in molecular size and concentration (Meyers et al. 1966; Seppälä et al. 1970 a, b; Seppälä \& Balazs 1969; Balazs et al. 1970).

Based on these observations it was suggested that the primary biological roles of hyaluronic acid in the body are shock absorption and vibration isolation (Balazs 1969). These are the functions of hyaluronic acid in synovial fluid and in the "elastic cushion" covering the articular cartilage surfaces. Thus, the main function of hyaluronic acid in the synovial fluid and in the "elastic cushion" of the cartilage surface is to protect the cells of articular cartilage and synovial tissue from the mechanical stress caused by movement of the joints. To maintain this biological function relatively large concentrations of high molecular weight hyaluronic acid with a large specific hydrated volume and high dynamic elasticity must be present in the synovial fluid.

It was our working hypothesis that in pathological conditions of the joint such as traumatic and degenerative arthritis in horses the protective function of the hyaluronic acid, for one reason or another, is dimished or completely disappears. In such cases the injection of high concentration, large molecular weight hyaluronic acid may restore the normal function of the joint, or at least improve the pathological condition. In the first series of experiments, reported in this paper, hyaluronic acid together with cortisone was injected into the joints of race horses with traumatic arthritis. The injection of hyaluronic acid alone and the fate of this biopolymer in the joint will be reported separately.

\section{MATERIALS}

Various batches of sterile hyaluronic acid were prepared from human umbilical cord or rooster comb for intra-articular injection. The sterile hyaluronic acid was prepared in our laboratory according to various modifications (Balazs \& Sweeney 1968; Swann 1968) of previously described preparation procedures (Blix \& Snellman 1945; Scott 1960). The protein content of the various batches varied somewhat, but was always less than $2 \%$ of the total dry organic material. The molecular weight of the hyaluronic acid was between $1 \times 10^{6}$ and $3 \times 10^{6}$. The sodium salt of hyaluronic acid was dissolved in a concentration of $2-7 \mathrm{mg}$ per $1 \mathrm{ml}$ of solution $(0.9 \% \mathrm{NaCl}, \mathrm{pH} 7.0)$. This preparation is 
an extremely viscous, paste-like substance that can pass through a 20-gauge needle without difficulty. Sterility tests were carried out on every batch of the preparation prior to clinical use.

The corticosteroid used for all injections was $6 \alpha$-methylprednisolone 21-acetate (Depo-Medrol $40 \mathrm{mg} / \mathrm{ml}$ : Upjohn Company, Kalamazoo, Michigan). Immediately prior to injection the DepoMedrol and hyaluronic acid were mixed in various volume ratios by aspirating both solutions into the same syringe. When DepoMedrol alone was injected, physiological saline was not used as diluent. Thus the concentration of cortisone in the fluids injected after dilution with hyaluronic acid was less than those without hyaluronic acid. The total amount of cortisone injected into the joint was, however, the same.

\section{METHODS}

The injections were sometimes made under local anesthesia, for which $1 \mathrm{ml}$ of carbocain was used. Great care was taken to prevent the anesthetic from accidentally entering the joint cavity. Usually the volume of synovial fluid removed was the same as the injected volume. In a few cases a considerable effusion with swelling of the joint was observed. In these cases enough synovial fluid to release the tension was removed from the joint prior to the injection of hyaluronic acid.

Twenty race horses (ages 3-10 years) with traumatic or degenerative arthritis were used in this experimental treatment. In most cases only 1 joint was involved, but in a few cases 2 diseased joints of the same animal were treated.

If any local tenderness over the ligament attachments was observed, the horse was excluded from this work. Each affected joint was also examined by X-rays to exclude fractures and avulsion of the ligament attachments. In most cases a narrowing of the joint space and/or osteophytic reaction were observed on the $\mathrm{X}$-rays. In order to secure correct diagnosis carbocain was injected into each affected joint the first time the horse was examined. If the symptom disappeared during local anesthesia, it was assumed that the injected joint was disabled. If some persisted the horse was also excluded.

Six of the horses had been treated earlier with Depo-Medrol with no or only short-term effects, symptoms recurring within $1-4$ weeks. 
The treatment and evaluation of the results are described in 2 groups. Twelve horses receiving cortisone and hyaluronic acid constitute Series I, and 8 horses receiving cortisone alone constitute Series II. The selection of horses for Series I and II was made randomly. Each series is subdivided into 3 groups according to the animal's ability to use the joint while racing, walking and standing.

Group I horses showed symptoms of functional disorder only during extreme stress on the joint, viz. during racing.

Group II horses showed symptoms of lameness or limping any time when in motion and when the joint was used, but not while standing.

Group III horses showed symptoms when standing, refusing to place their full weight on the diseased joint under any conditions.

In all 3 groups the skin over the diseased joint was usually considerably warmer than normal.

The effect of treatment was also evaluated on a functional basis, i.e. whether or not the horse could return to racing, how well the animal performed, and the duration of improvement. The results were defined as follows: $\mathrm{P}$ o o $\mathrm{r}$ : the horse continued to be lame and unable to race, or after a short period of improvement (less than 4 weeks) the lameness reappeared and the horse was unable to race inspite of repeated injections. F a i $r$ : the horse could race again, but did not perform so well as immediately prior to the onset of symptoms. Good: the horse returned to racing a few days after treatment, performing for a period of 3 months as well as he did before the symptoms started; this 3-month period was arbitrarily selected because we did not have the opportunity to follow the 2 cases in this group for a longer period of time. Ex e $1 \mathrm{l}$ e $\mathrm{n} t$ : the horse resumed racing performing as well as or better than it had prior to the manifestation of the symptoms and the improvement was maintained for more than 3 months.

\section{RESULTS}

\section{Injection of hyaluronic acid and cortisone (Series I)}

In all cases decrease in swelling was recorded after each injection. The swelling, however, seemed to decrease faster after injection of hyaluronic acid mixed with cortisone compared to 
Table 1. Summary of the clinical evaluation of intra-articular hyaluronic acid-cortisone and cortisone treatment.

\begin{tabular}{|c|c|c|c|c|c|c|}
\hline & \multirow{2}{*}{ Groups } & \multirow{2}{*}{$\begin{array}{c}\text { No. of } \\
\text { horses in } \\
\text { each group }\end{array}$} & \multicolumn{4}{|c|}{ No. of horses in each group evaluated } \\
\hline & & & poor & fair & good & excellent \\
\hline \multirow{4}{*}{ 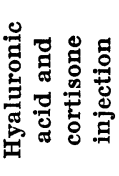 } & I & 4 & & & & 4 \\
\hline & II & 3 & & & & 3 \\
\hline & III & 5 & & 1 & 1 & 3 \\
\hline & Total & 12 & & 1 & 1 & 10 \\
\hline \multirow{4}{*}{ 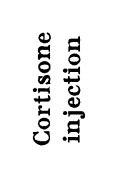 } & I & 4 & 3 & & & 1 \\
\hline & II & 2 & 2 & & & \\
\hline & III & 2 & 2 & & & \\
\hline & Total & 8 & 7 & & & 1 \\
\hline
\end{tabular}

injections of only cortisone. The affected joints, which showed a raise in temperature, had a rapid normalization of the skin temperature after injection of hyaluronic acid together with cortisone, but usually not after injection of only cortisone.

\section{Group I}

$\mathrm{C}$ a s e $\mathrm{H}$ 7. This 9-year-old standard-bred gelding performed poorly, bearing out during a race. Two days later his right front fetlock joint was swollen and painful, and the temperature of the overlying skin was increased. Hyaluronic acid $(3 \mathrm{ml} ; 3 \mathrm{mg} / \mathrm{ml})$ and Depo-Medrol $(2.5 \mathrm{ml})$ were injected. Two days later the horse raced without symptoms, finishing third; the horse won the next 3 races. The animal was still racing well after more than 6 months. (Excellent).

C a s e H 8. This 5-year-old standard-bred gelding bearing out badly, had raced for approx. 6 months. He had raised skin temperature over the right front coffin joint, but no swelling was evident. Depo-Medrol $(2.5 \mathrm{ml})$ was injected and slight improvement was observed. After racing poorly for 3 weeks lameness recurred in the same coffin joint. Hyaluronic acid $(3 \mathrm{ml} ; 3 \mathrm{mg} /$ $\mathrm{ml})$ and Depo-Medrol $(2.5 \mathrm{ml})$ were injected. Three days later the horse resumed racing and showed good results for 3 months. The horse was then moved to another racetrack where continued follow-up was not possible. (Excellent). 
C a s e H 9. This 5-year-old standard-bred mare was bearing in badly in racing. Examination revealed pain and raised skin temperature over the left front coffin joint. Depo-Medrol (2.5 ml) was injected, but no immediate improvement could be observed. Due to the winter interval the horse was allowed to rest for 2 months, after which considerable improvement in racing performance was observed. After 2 months of racing the horse again began to perform poorly. Examination revealed severe pain and raised skin temperature over the left front coffin joint. Hyaluronic acid $(8 \mathrm{ml} ; 3 \mathrm{mg} / \mathrm{ml})$ and Depo-Medrol $(2.5 \mathrm{ml})$ were injected; after 6 days the horse was racing again - winning the first race and continuing to perform well for a period of almost 3 months. Following this period the horse again began to perform poorly, bearing in while racing, and the same symptoms recurred in the left front coffin joint - although they were less pronounced than on previous examination. Hyaluronic acid $(3.5 \mathrm{ml} ; 3 \mathrm{mg} / \mathrm{ml})$ and Depo-Medrol $(2.5 \mathrm{ml})$ were injected. The horse resumed racing after 6 days, winning the first race and continuing to race well for another month, after which the same symptoms recurred in the same joint. Hyaluronic acid $(1.5 \mathrm{ml}$; $7 \mathrm{mg} / \mathrm{ml}$ ) and Depo-Medrol $(1 \mathrm{ml})$ were injected. Three days later the horse was placed fifth in a race and won the next race. The horse was racing well more than 3 months after the last injection. (Excellent).

C a s e H 11. This 5-year-old standard-bred gelding was performing badly, bearing in while racing, due to pain and swelling in the left front coffin and fetlock joints. Hyaluronic acid $(2 \mathrm{ml}$; $7 \mathrm{mg} / \mathrm{ml}$ ) and Depo-Medrol $(1 \mathrm{ml})$ were injected. Three days the horse returned to racing and was still performing well after more than 6 months. (Excellent).

\section{Group II}

Ca s e H 1. This 8-year-old standard-bred gelding showed pain and swelling in the right carpal joint for several months. Hyaluronic acid $(3 \mathrm{ml} ; 3 \mathrm{mg} / \mathrm{ml})$ and Depo-Medrol $(3 \mathrm{ml})$ were injected. The horse won 7 races within the following 6 months, compared to winning 3 times during the 6 months prior to the onset of symptoms. (Excellent).

C a s e H 2. This 3-year-old standard-bred gelding had a rather long history of recurrent lameness due to some pathology 
in the left stiffel joint. The horse was treated with Depo-Medrol for 1 month but showed almost no improvement. After the last Depo-Medrol injection the horse was trained, but lameness recurred until the horse could barely walk. Hyaluronic acid ( $3 \mathrm{ml}$; $3 \mathrm{mg} / \mathrm{ml})$ and Depo-Medrol $(2.5 \mathrm{ml})$ were injected. The horse was immediately able to walk without displaying any symptoms and, after 2 days, training was resumed. After 3 weeks the horse resumed racing and still after more than 6 months was performing as well as prior to the onset of symptoms. (Excellent).

C a s e H 10. This 3-year-old standard-bred filly was lame and unable to train for several weeks due to inflammation in both carpal joints. Depo-Medrol $(2.5 \mathrm{ml})$ was injected into both joints, but no improvement could be observed. Four weeks later hyaluronic acid $(3.5 \mathrm{ml} ; 3 \mathrm{mg} / \mathrm{ml})$ and Depo-Medrol $(2.5 \mathrm{ml})$ were injected. Immediate improvement could be observed and, after 4 days, the horse again raced well. The symptoms recurred $2 \frac{1}{2}$ months later. Hyaluronic acid $(3 \mathrm{ml} ; 3 \mathrm{mg} / \mathrm{ml})$ and DepoMedrol $(2.5 \mathrm{ml})$ were injected. The horse resumed racing after 7 days and was still performing well 5 months later. (Excellent).

\section{Group III}

C a s e H3. This 4-year-old standard-bred mare had recurrent symptoms in the left front coffin joint for a period of 1 year. During the preceding year the horse had received 5 injections of Depo-Medrol in this joint. Following each injection the horse was able to race for approximately 3 weeks, after which lameness recurred. After a sixth injection of Depo-Medrol no improvement could be observed and the horse again was unable to race. Pain and raised skin temperature over the front coffin joint was observed. The animal rested for 4 weeks, but the symptoms increased in severity and, at the end of this period, the horse refused to place full weight on the affected joint. Hyaluronic acid $(9 \mathrm{ml} ; 3 \mathrm{mg} / \mathrm{ml})$ and Depo-Medrol $(5 \mathrm{ml})$ were injected into the joint. Two days later the horse put full weight on the affected leg and 4 weeks later, resumed racing. Lameness recurred 3 months later. Hyaluronic acid ( $3 \mathrm{ml} ; 3 \mathrm{mg} / \mathrm{ml}$ ) and Depo-Medrol $(2 \mathrm{ml})$ were injected into the same coffin joint. Within a couple of days the horse raced again and was still racing well 4 months later. (Excellent). 
C a s e H 5. This 7-year-old standard-bred gelding had symptoms of pain in the left carpal and front fetlock joint and apparently had strained suspensory ligaments in the same leg. Hyaluronic acid $(3 \mathrm{ml} ; 3 \mathrm{mg} / \mathrm{ml})$ and Depo-Medrol $(2.5 \mathrm{ml}$ ) were injected into both affected joints. The horse raced within 5 days and continued to race well for 3 months. The animal was then transferred to another racetrack where further follow-up studies were not possible. (Excellent).

$\mathrm{C}$ a s e $\mathrm{H}$ 6. This 9-year-old standard-bred gelding had a long history of pain and swelling in the left tarsal joint and was unable to race for several months. Hyaluronic acid $(3 \mathrm{ml} ; 3 \mathrm{mg} / \mathrm{ml}$ ) and Depo-Medrol $(2.5 \mathrm{ml})$ were injected into the joint. The horse raced within 1 week, and after 7 months was still racing well. (Excellent).

C a s e H 12. This 8-year-old standard-bred stallion had increasing navicular trouble in the 2 front hooves for 3 years and was treated with Depo-Medrol without showing improvement. The horse showed great difficulty in walking, apparently due to severe pain, and tried to ease weight-bearing on standing by lifting one front leg. Hyaluronic acid (3 ml; $3 \mathrm{mg} / \mathrm{ml})$ and DepoMedrol ( $2 \mathrm{ml}$ ) were injected into each hoof joint. Immediate improvement was observed in regard to swelling, skin temperature and pain. The horse was able to race fairly well within 2 weeks, but lameness recurred 2 months later. At that time the animal was transferred to another racetrack where further follow-up studies were not possible. (Fair).

C a s e H 13. This 8-year-old standard-bred gelding was lame for several months because of a swollen and painful left tarsal joint. Hyaluronic acid $(3 \mathrm{ml} ; 3 \mathrm{mg} / \mathrm{ml})$ and Depo-Medrol $(3 \mathrm{ml})$ were injected. Immediate improvement was observed and the horse raced well within 3 weeks. One and a half months later the horse became lame in another joint. At that time the animal was transferred to another racetrack where further follow-up studies were not possible. (Good).

\section{Injection of cortisone (Series II) Group I}

C a s e C 1. This 4-year-old standard-bred stallion had swollen and painful carpal joints in both legs for a period of 2 weeks. Depo-Medrol (2.5 ml) was injected into each carpal joint. Im- 
provement was observed for 1 month, but the horse was unable to race. Lameness returned and another injection of Depo-Medrol into each joint did not produce any improvement. (Poor).

$\mathrm{C}$ a s e $\mathrm{C} 2$. This 7-year-old standard-bred gelding had symptoms of swelling and pain in the left front fetlock joint for a period of 2 weeks. Depo-Medrol $(2.5 \mathrm{ml})$ was injected and the horse was immediately able to race well again. The horse won the next race and continued to race well for more than 4 months. (Excellent).

C a s e C 3. This 4-year-old standard-bred mare had a swollen and painful left carpal joint for a period of 2 weeks. Depo-Medrol $(2.5 \mathrm{ml})$ was injected into the joint twice within a 2-week period, and the horse was able to race well after each injection. Four weeks after the first injection the horse was again unable to race, and a further injection of Depo-Medrol $(2.5 \mathrm{ml})$ produced no response. (Poor).

$\mathrm{C}$ a s e C 4. This 3-year-old standard-bred mare had a swollen and painful left front coffin joint for more than 2 weeks. DepoMedrol $(2.5 \mathrm{ml})$ was injected and improvement was evident for a period of 2 weeks, after which the same symptoms recurred. After another injection of Depo-Medrol $(2.5 \mathrm{ml})$ improvement was noted for a period of 4 weeks, followed by a relapse. After the third injection of Depo-Medrol $(2.5 \mathrm{ml})$ improvement lasted for 3 weeks, but the horse then became lame again. Depo-Medrol $(2.5 \mathrm{ml})$ improvement lasted for 3 weeks, but the horse then became lame again. Depo-Medrol $(2.5 \mathrm{ml})$ was reinjected, but no improvement was observed and after 2 months the horse was still lame. (Poor).

\section{Group II}

C a s e C 5. This 7-year-old standard-bred gelding had a swollen and painful right front fetlock joint for several weeks. Depo-Medrol $(2.5 \mathrm{ml})$ was injected 3 times within a 12-week period. During the periods between the first and second and the second and third injections the horse raced for about 3 weeks. After the last injection of Depo-Medrol the joint showed no improvement. (Poor).

C a s e C 6. This 10-year-old standard-bred gelding had a swollen and painful right front fetlock joint for a long period of time. Depo-Medrol $(2.5 \mathrm{ml})$ was injected and an immediate 
improvement was observed and the horse was able to race. After 4 weeks, however, the horse again became lame. Following this relapse Depo-Medrol (2.5 $\mathrm{ml})$ was again injected. The horse was free of symptoms for 3 weeks. After the second relapse the joint was injected repeatedly with Depo-Medrol without results. (Poor).

\section{Group III}

C a s e C 7. This 7-year-old standard-bred gelding had arthritis in both carpal joints for several months. Depo-Medrol (2.5 ml) was injected into each carpal joint, after which the horse raced well for 4 weeks, and then a relapse occurred. After another injection of Depo-Medrol (2.5 ml) into each joint some improvement could be observed, but in 4 weeks the same symptoms recurred and the horse was unable to race. (Poor).

C a s e C 8. This 8-year-old standard-bred gelding had a swollen and painful left front fetlock joint. Depo-Medrol (2.5 ml) was injected and the next day dramatic improvement was observed. The horse raced well for about 1 month; the animal was then involved in an accident and was retired from racing for 1 month. Following this period of rest the horse continued to race well for 3 weeks, after which time the joint became swollen and painful and lameness was evident. Depo-Medrol (2.5 $\mathrm{ml})$ was injected into the same joint and an immediate improvement was observed, which lasted for approx. 2 weeks. At that time the symptoms and lameness recurred to such a degree that the horse never was able to race again. (Poor).

\section{DISCUSSION}

Table 1 summarizes the results of the treatment in both series. It is obvious that the cortisone treatment in combination with hyaluronic acid resulted in a more lasting and better improvement than when cortisone alone was used. Seven horses treated with hyaluronic acid and cortisone were able to return to racing within a short period of time and performed well without further treatment for the entire follow-up period (3-7 months; evaluation: excellent). Three other horses required 1 additional injection in order to perform so well; results of this treatment also were judged to be excellent. Two horses in this series showed about the same degree of improvement, but since they could be 
followed for only $2 \frac{1}{2}$ months the evaluations of the treatments were judged to be fair and good, respectively.

Six horses in Series I were treated with cortisone prior to the hyaluronic acid-cortisone injections. Since cortisone treatment alone did not improve the function of the diseased joint the improvement observed after hyaluronic acid treatment of these cases is especially significant.

Cortisone treatment of $\mathbf{8}$ horses produced immediate improvement, and, in most cases, joint function was so good that the horses were able to race well for short periods of time. In 7 of the 8 cases, however, improvement was temporary. After repeated injection of cortisone the symptoms remained unchanged and, in many cases, rapid deterioration of the function of the joint was obvious after continued exercise.

It was long ago suggested that hyaluronic acid or hyaluronic acid accompanied by certain proteins of the synovial fluid (synovial "mucin") should be used in certain pathological conditions of the joint (Balazs, unpublished data 1945). This suggestion was based on the observation that the healing of artificially inflicted wound on the surface of the articular cartilage heals faster, and that the cartilagenous callous formation between broken ends of long bones is stimulated by local application of synovial "mucin" (Balazs \& Piller 1943). This opinion is supported by the work of Bruckschen (1957).

One explanation of the good results of our treatment of track horses with traumatic arthritis might be that the injected hyaluronic acid adheres to the surface of the articular cartilage or the synovial tissue. In the first case the hyaluronic acid interacting with the "elastic cushion" may improve its normal shock absorption and lubricating functions. In the second case the injected hyaluronic acid accumulating around the synovial cells may suppress their hyaluronic acid production. Both of these possible mechanisms would improve the function of the joint by decreasing exudate formation and by protecting the cartilage surfaces.

Another explanation may be that the viscous hyaluronic acid in which the water-insoluble Depo-Medrol particles are dispersed serves as a better dispersing agent than physiological salt solution. One can observe under the light microscope that the DepoMedrol particles disperse in hyaluronic acid solution or in synovial fluid from particles much finer and more equal in size 
than does Depo-Medrol in the original form or diluted with physiological salt solution. It must be pointed out, however, that the synovial fluid is viscous enough - even in the pathological joint - to provide the same dispersion and stabilization effect on the Depo-Medrol particles as does the hyaluronic acid. The Depo-Medrol particles disappear first from the synovial fluid; $48 \mathrm{hrs}$. after injection the aspirated synovial fluid shows no turbidity, which suggests that the cortisone is completely dissolved or is absorbed by the tissue surfaces of the joint.

Improvement of clinical symptoms is frequently observed in different arthritic conditions after cortisone treatment. Parallel with this improvement a decrease in the value of synovial fluid and an increase of hyaluronic acid concentration occur (for reference see Sundblad 1965), but the total amount of hyaluronic acid in the synovial fluid decreases.

It was also shown that the viscoelastic qualities of the hyaluronic acid change after cortisone treatment. The viscous and elastic moduli increase in the synovial fluid of human rheumatoid arthritic (Balazs et al. 1970) and osteoarthritic joints (Meyers et al. 1966).

Thus, intra-articular cortisone treatment normalizes the metabolism of hyaluronic acid in several human pathological conditions. On the other hand it is well known that prolonged intraarticular cortisone treatment causes severe damage to the articular cartilage (see the introduction) and in the blood vessel system of the synovial tissue (Brånemark et al. 1967). It is important to point out, however, that Depo-Medrol is one of the few preparations that did not cause microcirculatory damage.

A further possible explanation of the effect of hyaluronic acid is to assume that this biopolymer itself provokes a reaction on the surface of the articular cartilage or in the synovial tissue, which itself has a controlling effect on the pathological process. In this connection some preliminary results of work now in progress by the authors of this study should be mentioned. When hyaluronic acid is injected without cortisone into normal or arthritic (degenerative or traumatic) equine joints a rapid influx of predominantly mononuclear cells occurs. It is possible that this macrophage invasion is instrumental in producing improvement in the condition of the joint, especially since the intra-articular injection of hyaluronic acid without cortisone in the few cases tested - showed as good or better clinical im- 
provement than did the injection of hyaluronic acid with DepoMedrol. In another series of experiments mechanical damage was inflicted on the surface of the articular cartilage in dogs and monkeys. During the healing process hyaluronic acid or physiological salt solution was injected several times into the joint cavity. The healing of the cartilage surface was smoother without pannus or visible secondary effects in joints injected with hyaluorinc acid, while in joints injected with physiological salt solution pannus formation always occurred and joint effusion frequently occurred. Independent of our investigation, similar findings were recently reported in dogs by Curri \& Campailla (1967) and in one human patient (Stracker 1967).

Our purpose was to point out the various possible mechanisms that may play a role in the improvement of joint function after intra-articular administration of cortisone suspended in hyaluronic acid. It is obvious that, at the moment, no explanation of the mechanism of clinical improvement can be offered. We hope that injection of hyaluronic acid without cortisone into pathological joints (Rydell \& Balazs, in progress) will provide valuable information towards the solution of this problem.

\section{REFERENCES}

Balazs, E. A.: Physical chemistry of hyaluronic acid. Fed. Proc. 1958, 17, 1086-1093.

Balazs, E. A.: Physiology of the vitreous body. In Importance of the Vitreous Body in Retina Surgery with Special Emphasis on Reoperations. ed. C. L. Schepens, C. V. Mosby, St. Louis 1960, $29-48$.

Balazs, E. A.: Sediment volume and viscoelastic behaviour of hyaluronic acid solutions. Fed. Proc. 1966, 25, 1817-1822.

Balazs, E. A.: Viscoelastic properties of hyaluronic acid and biological lubrication. Univ. Mich. Med. Ctr.J., Special Issue Dec. 1968, 255-259.

Balazs, E. A.: Some aspects of the aging and radiation sensitivity of the intercellular matrix with special regard to hyaluronic acid in synovial fluid and vitreous. In Thule International Symposium: Aging of Connective and Skeletal Tissue. ed. A. Engel \& T. Larsson. Nordiska Bokhandels Förlag, Stockholm 1969.

Balazs, E. A. \& L. Piller: The formation of synovial fluid. Magy. orv. Arch. 1943, 44, 3-7.

Balazs, E. A. \& D. B. Sweeney: The replacement of the vitreous body in the owl monkey by reconstituted vitreous and by hyaluronic acid. Mod. Probl. Ophthal. (Basel) 1966, 4, 230—232. 
Balazs, E. A., G. D. Bloom \& D. A. Swann: Fine structure and glycosaminoglycan content of the surface layer of articular cartilage. Fed. Proc. 1966, 25, 1813-1816.

Balazs, E. A., P. O. Seppälä, D. A. Gibbs, I. F. Duff \& E. W. Merrill: Effect of aging on the viscoelastic and chemical properties of human synovial fluid. Arthr. and Rheum. 1967, 10, 264.

Balazs, E. A. \& D. B. Sweeney: The injection of hyaluronic acid and reconstituted vitreous into the vitreous cavity. In New and Controversial Aspects of Retinal Detachment. ed. A. McPherson. Hoeber Medical Division, New York 1968, 371-376.

Balazs, E. A., P. O. Seppälä \& I. F. Duff: Hyaluronic acid in synovial fluid. V. Effect of repeated intra-articular hydrocortisone injections on the viscoelastic and chemical properties of rheumatoid synovial fluid. Arthr. and Rheum. 1970. In press.

Blix, G. \& O. Snellman: On chondroitin sulphuric acid and hyaluronic acid. Arkiv Kemi 1945, 19A, 1-19.

Blumberg, B. S.\& A. G. Ogston: The effects of proteolytic enzymes on the hyaluronic acid complex of ox synovial fluid. Biochem. J. $1957,66,342-346$.

Brånemark, P.-I. \& I. Goldie: Observations on the action of prednisolone tertiary butyl acetate (Codelcortone TBA) and methylprednisolone acetate (depomedrone) on normal soft tissues. Acta rheum. scand. 1967, 13, 241-256.

Bruckschen, E. G.: Gewebsreaktionen nach Implantation von Hyaluronsäure. (Tissue reaction after hyaluronic acid installment). Exuerientia (Basel) 1957, 19, 289-290.

Chandler, G. N. \& V. Wright: The deleterious effect of intra articular hydrocortisone injections. Lancet $1958,2,661-663$.

Chandler, G. N., D. T. Jones, V. Wright \& S. J. Hartfall: Charcot's arthropathy following intra-articular hydrocortisone. Brit. med. J. 1959, 1, 952-953.

Curri, S. B. \& E. Campailla: Acido jaluronico e condrogenesi : influenza del mucopolysaccharide sui processi riparativi della dartilagine. (Hyaluronic acid and chondrogenesis: the influence of mucopolysaccharides on cartilage repair). Biochem. Biol. sper. 1967, $6,32-71$.

Gibbs, D. A., E. W. Merrill, K. A. Smith \& E. A. Balazs: The rheology of hyaluronic acid. Biopolymers 1968, 6, 777-791.

Laurent, T. C.: Physico-Chemical Studies on Hyaluronic Acid. Akademisk Avhandling, Almquist \& Wiksell, Uppsala 1957.

McKay, A. G.: Articular cartilage erosion. Canad. vet. J. 1967, 8, 134135.

Meyers, $K . R$., S. Negami \& R. K. White: Dynamic mechanical properties of synovial fluid. Biorheology 1966, 3, 197-209.

O'Connor, J. T.: The untoward effects of cortical steroids in the horse. J. Amer. vet. med. Ass. 1968, 153, 1614-1617.

Ogston, A. G. \& J. E. Stanier: The physiological function of hyaluronic acid in synovial fluid: viscous; elastic; and lubricational properties. J. Physiol. (Lond.) 1953, 119, 244-252. 
Preston, B. N., M. Davies \& A. G. Ogston: The composition and physiochemical properties of hyaluronic acids prepared from ox synovial fluid and from a case of mesothelioma. Biochem. J. $1965,96,449-474$.

Rydell, N. \& E. A. Balazs: Synovial joint reaction after injection of hyaluronic acid. In progress.

Salter, R. B., A. Gross \& J. H. Hale: Hydrocortisone arthropathy: an experimental investigation. Canad. med. Ass. J. 1967, 97, 374377.

Scott, $J . E .:$ Alipathic ammonium salts in the assay of acid polysaccharides from tissues. Meth. biochem. Anal. 1960, 8, 145-197.

Seppälä, P. O. \& E. A. Balazs: Hyaluronic acid in synovial fluid. III. Effect of maturation and aging on the chemical properties of bovine synovial fluid of different joints. J. Geront. 1969, 24, $309-314$.

Seppälä, P. O., E. A. Balazs \& I. F. Duff: Hyaluronic acid in synovial fluid. II. Effect of aging on the chemical properties of human synovial fluid. Arthr. and Rheum. 1970 a. In press.

Seppälä, P. O., D. A. Gibbs \& E. A. Balazs: Hyaluronic acid in synovial fluid. IV. Viscoelasticity of human and bovine synovial fluid during aging and in various pathological conditions. Biochim. biophys. Acta (Amst.) 1970 b. In press.

Stracker, $O$. A.: Synovia und degenerative Gelenkserkrankungen. (The synovium and degenerative joint diseases). Z. Orthop. 1967, 4, $424-432$.

Sundblad, L.: Glycosaminoglycans and glycoproteins in synovial fluid. In The Amino Sugars, vol. 2-A. Distribution and Biological Role, 230-250. ed. E. A. Balazs \& R. W. Jeanloz. Academic Press, New York 1965.

Swann, D. A.: Studies on hyaluronic acid. 1. Preparation and properties of rooster comb hyaluronic acid. Biochim. biophys. Acta (Amst.) 1968, 156, 17-30.

Zacharic, L.: The deleterious effect of corticosteroids administration topically in particular intra-articularly. Acta orthop. scand. $1965,36,127-136$.

österlin, S. \& E. A. Balazs: Macromolecular composition and fine structure of the vitreous in the owl monkey. Exp. Eye Res. 1968, 7, $534-545$.

\section{SUMMARY}

Twelve horses with traumatic arthritis were treated with intraarticular injection of hyaluronic acid mixed with cortisone and the results compared with 6 horses treated only with cortisone. There was a significantly better improvement in the group injected with a mixture of hyaluronic acid and cortisone. Further studies have given the same results in traumatic arthritis in horses if hyaluronic acid alone is injected. 
After injection of hyaluronic acid a large number of granulated monocytes appeared in the synovial fluid, but no inflammatory signs were observed. It is possible that this macrophage invasion is instrumental in producing improvement in the condition of the joint. The injected hyaluronic acid may also adhere to the surface of articular cartilage producing an "elastic cushion" protecting the cartilage surface.

Experimental mechanical damage was also inflicted on the surface of articular cartilage in dogs and monkeys, and smoother healing was achieved if hyaluronic acid was injected into the joints after the damage.

Injections of hyaluronic acid seem to be of value in treating traumatic arthritis or similar conditions.

\section{SAMMANFATTNING}

Hyaluronsyra i synovialvätska. VI. Effekt av intraartikulära hyaluronsyreinfektioner på symtom vid arthrittillstånd hos kapplöpningshäster.

Tolv hästar med traumatisk arthrit har behandlats med intraartikulära hyaluronsyre-cortisoninjektioner och resultatet jämförts med 6 fall som endast behandlats med intraartikulära cortisoninjektioner. De hästar som behandlades med hyaluronsyra-cortisoninjektioner uppvisade en signifikant förbättring jämfört med kontrollgruppens. Senare studier har visat att samma goda resultat kan erhållas om enbart hyaluronsyra injiceras intraartikulärt vid traumatiska arthriter.

Efter intraartikulära injektioner av hyaluronsyra uppträder ett stort antal granulerade monocyter i synovialvätskan men inga kliniska tecken på inflammation kan observeras. Det är möjligt att det ökade antal macrophager som uppträder i ledvätskan efter hyaluronsyreinjektion har betydelse för den observerade bättringen av ledsjukdomen. Den injicerade hyaluronsyran kan också tänkas bilda en tunn film på ledbroskets yta och på så sätt bilda en elastisk kudde, vilken skyddar broskytan mot nötning och även fungerar som en stötdämpare.

Mekanisk skada som åstadkommits i ledbrosket hos hundar och åsnor visade en förbättrad läkning, om leden efter skadans uppkomst behandlades med hyaluronsyreinjektioner.

Det förefaller som intraartikulära hyaluronsyreinjektioner vid traumatiska arthriter och liknande sjukdomstillstånd är av värde vid behandlingen av dessa tillstånd.

(Received June 25, 1969). 